\title{
Soft Skills In Practice And In Education: An Evaluation
}

\author{
Harald Wahl, UAS Technikum Wien, Austria \\ Christian Kaufmann, UAS Technikum Wien, Austria \\ Florian Eckkrammer, UAS Technikum Wien, Austria \\ Alexander Mense, UAS Technikum Wien, Austria \\ Helmut Gollner, UAS Technikum Wien, Austria \\ Christian Himmler, UAS Technikum Wien, Austria \\ Wolf Rogner, UAS Technikum Wien, Austria \\ Thomas Baierl, UAS Technikum Wien, Austria \\ Roman Slobodian, UAS Technikum Wien, Austria
}

\begin{abstract}
The paper measures the soft skills needs of companies and industry to technical oriented academic graduates, especially coming from IT course programs like business informatics, computer science, or information management. Therefore, between March and September 2010, two groups of researchers at the University of Applied Sciences (UAS) Technikum Vienna analyzed job profiles and the intended denotation of certain keywords. Primarily, one group worked on the statistical content analysis of job offers which could be found in Austrian newspapers or were provided by online job platforms. The other group developed a survey to be sent to several companies in Austria and was addressed to human resources departments. The paper explains the evaluation results in details and discusses its necessary implication on academic curriculum design.
\end{abstract}

Keywords: Soft Skills; IT Course Programs; Professional Needs; Curriculum Design

\section{INTRODUCTION}

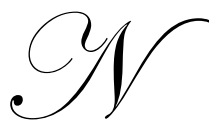

aturally, academic graduates of technical oriented course programs are well qualified in technical skills. In the last years it has become more and more important that academic engineers are additionally trained in soft skills. The University of Applied Sciences (UAS) Technikum Wien provides several technical oriented course programs. Strategically, all course programs at the UAS Technikum Wien follow the rule that education must include technical content as well as non-technical content and soft skills. To illustrate the importance of soft skills in technical oriented academic education, it is necessary to know which requirements companies really have in this aspect on graduates.

Is there a demand for academic IT education to put more emphasis on soft skills rather than traditional IT related subjects? Between March and September 2010, two groups of researchers at the University of Applied Sciences Technikum Vienna tried to find the answer to this assumption. On the one hand they analyzed job profiles and the intended denotation of certain keywords and on the other hand they conducted a survey with several companies. This paper details on the statistical analysis of the studied job profiles available through Austrian newspapers and the conclusions coming from the survey. Insights into soft skill requirements are provided as well as some approaches academic institutions could follow in order to improve their course programs.

\section{THE EDUCATIONAL GAP}

The gap between academic education and required skill sets in industry has been addressed on several occasions. Especially in IT oriented branches, Problem Based Learning was subject of several academic studies and topic on conferences covering best practices in academic education. Central to these efforts is the question whether 
academic IT related education satisfies the demands and requirements of the IT industry. Traditional academic programs focus on core skills like mathematics, algorithms, programming and information management. Peripheral skills, especially soft skills, are offered mostly in optional courses and subject to the voluntary selection by the student. Technological advances need to be reflected in course content. Professional engagement on the other hand rarely involves application of mathematical algorithms or programming to problem solving. Work is organized in project oriented teams, requires permanent maintenance of flow of clear and concise information. Grown demands to the mobility of employees require them to communicate with peers from different cultures and languages.

\section{INTRODUCTORY QUESTIONS}

Academic course programs are well known and determined. Contrariwise, industrial requirements are clearly defined rarely. It is not clear whether academic education, specifically in the area of Information Technology meets the requirements in professional employment. This paper tries to identify specific requirements for soft skills in the IT industry by analyzing IT related job descriptions.

\section{METHODOLOGICAL APPROACH AND DATA SOURCES}

Realistic descriptions of demands for specific soft skills can be found in publicly announced job proposals. Companies announce vacancies in newspapers, on their respective home page and in publicly available online databases. So, screening of job proposals will yield in trustful information. IT related job proposals are maintained both conventionally, being published in newspapers as well as electronically. From March 2010 up to September 2010 we collected descriptions of job proposals of IT related vacancies. A first screening of available data sources showed that online proposals offered by "Der Standard" and "Die Presse" - two domestic newspapers - were similar, with "Der Standard" having the widest spectrum of IT related offerings. "Der Standard" also provides a comprehensive online database that resembles the proposals in print. All IT related job offers available were collected. The online database of "Der Standard" was regularly queried for IT related job offers. All offers were saved both as reference and as a local copy of the content. Duplicates have been marked in the evaluation and counted only once to eliminate statistical distortion in favor of some soft skills. All material collected is available in electronic form for further reference.

\section{IDENTIFICATION OF SOFT SKILLS}

The "Austrian Workplace Management Services" (AMS) research branch offers a comprehensive list of qualifications required for jobs in selected industrial branches as web services. The list contributes two factors to this research. Firstly, required qualifications are grouped into domain specific functional skills and generic soft skills respectively. Secondly, generic soft skills are further attributed to enhance understanding and comprehension of their denotation. The second aspect was taken as the foundation to our list of soft skills. A quick scan through the job offers verified this approach. Table 1 gives an overview of soft skills clustered into categories. This list was taken as reference for both the survey of our survey as well as our screening of job offerings.

Table 1: Categories of soft skills evaluated.

\begin{tabular}{|l|l|l|}
\hline \multicolumn{2}{|c|}{ Original skills in German } & \multicolumn{1}{|c|}{ English } \\
\hline Category & Skill Alias & Translation \\
\hline $\begin{array}{l}\text { Selbstmanagement, } \\
\text { Selbstmotivation }\end{array}$ & $\begin{array}{l}\text { eigenverantwortlich } \\
\text { selbständig } \\
\text { eigentständig } \\
\text { untern. Denken } \\
\text { wirtschaftl. Denken } \\
\text { strukturierter Arbeitsstil }\end{array}$ & Self-management, self-motivation \\
\hline Stressresistenz & $\begin{array}{l}\text { flexibel } \\
\text { anpassungsfähig }\end{array}$ & \\
\hline
\end{tabular}




\begin{tabular}{|c|c|c|}
\hline \multicolumn{2}{|c|}{ Original skills in German } & English \\
\hline Category & Skill Alias & Translation \\
\hline Lernbereitschaft & $\begin{array}{l}\text { Weiterbildung angeboten } \\
\text { Weiterbildung gefordert } \\
\text { Weiterbildung gewünscht }\end{array}$ & $\begin{array}{l}\text { Willingness for further education or } \\
\text { training }\end{array}$ \\
\hline Analytische Fähigkeiten & $\begin{array}{l}\text { eigenständige Problemlösungsfähigkeit } \\
\text { analytisches Denkvermögen }\end{array}$ & Analytical capabilities \\
\hline Teamintegration & $\begin{array}{l}\text { Arbeit in Team } \\
\text { Teamfähigkeit } \\
\text { Integrationsfähigkei } \\
\text { anpassungsfähig } \\
\text { Freude am Arbeiten im Team }\end{array}$ & Team integration \\
\hline Teammanagement & $\begin{array}{l}\text { Verantwortung für Mitarbeiter } \\
\text { Führung von Mitarbeiter } \\
\text { Teamführung } \\
\text { Führen kleines Team }\end{array}$ & Team management \\
\hline Zielorientierung & $\begin{array}{l}\text { Zielerreichung } \\
\text { Durchsetzungsstärke } \\
\text { Durchsetzungsvermögen } \\
\text { selbstsicheres Auftreten } \\
\text { Überzeugungsstärke } \\
\text { Lösungsorientierter Arbeitsstil }\end{array}$ & Focus on goals and targets \\
\hline Kommunikation & $\begin{array}{l}\text { Kommunikationsstärke } \\
\text { kommunikativ } \\
\ldots \text { in Verbindung mit anderen Abteilungen... } \\
\text { aktiver Wissensaustausch }\end{array}$ & $\begin{array}{l}\text { Communication skills } \\
\text { interpreted as internal to the company }\end{array}$ \\
\hline Präsentation & $\begin{array}{l}\text { Präsentationsfähigkeiten } \\
\text { Überzeugungskraft } \\
\text { selbstsicheres Auftreten } \\
\text { Kundenorientierung }\end{array}$ & $\begin{array}{l}\text { Presentation skills } \\
\text { interpreted as external to the company, } \\
\text { client related }\end{array}$ \\
\hline Englisch & & English required \\
\hline Ost-Sprachen & & Languages spoken in CEE \\
\hline sonst. Fremdsprachen & & Other foreign languages \\
\hline Reisebereitschaft in Austria & $\begin{array}{l}\text { auch implizit bei Betreuung von Niederlassungen } \\
\text { im Inland }\end{array}$ & $\begin{array}{l}\text { Readiness to domestic business travel. } \\
\text { Local support for domestic subsidiaries } \\
\text { included }\end{array}$ \\
\hline Reisebereitschaft international & $\begin{array}{l}\text { auch implizit bei Betreuung von Niederlassungen } \\
\text { im Ausland }\end{array}$ & $\begin{array}{l}\text { Readiness to international business travel. } \\
\text { Local support for international subsidiaries } \\
\text { included }\end{array}$ \\
\hline Projektmanagementskills ${ }^{l}$ & $\begin{array}{l}\text { Managen von Projekten } \\
\text { Erfahrung im Projektmanagement } \\
\text { Umsetzung in Projekten }\end{array}$ & Project management skills \\
\hline
\end{tabular}

${ }^{1}$ Project management was initially not rated a soft skill. Formal training and certification is offered by several public and private institutions. The way how this requirement was phrased and the fact that nearly one third of the vacancies informally demanded certain skills, it was later added to the list. 


\section{SCREENING OF JOB DESCRIPTIONS}

Two methods of screening were evaluated, manual and automatic screening. Manual screening by reading through all job offerings is slow and might introduce human errors. The major advantage of this method is the ability of the reader to adjust to changes in paraphrasing or shift in denotations. Automatic screening using keyword search requires intelligent algorithms to classify homonyms and synonyms.

We chose the first method mainly because the risk of errors introduced seemed acceptable and it was outweighed by the effort to identify and test a suitable program for automated analysis. As all data is available in electronic form, more detailed automated research can be carried out at a later time. Screening did not only cover soft skills mentioned in the job offerings. Job type, geographical distribution of vacancies, educational, and formal skills required were also recorded. Duplicates were identified and eliminated from the statistically relevant data. All data was gathered in electronic form for further statistical analysis.

\section{ACQUIRING BACKGROUND INFORMATION}

During data collection it became obvious, that a single company, ePunkt Internet Recruiting GmbH. dominates the market of IT related job advertisements and personnel recruiting. In a personal meeting between Mag. Daniel Marwan, owner and general manager of ePunkt and Wolf Rogner in Linz, September 2nd 2010 Mr. Marwan gave an insight into the work of ePunkt. The denotation of keywords like stress resilience, self-management and self-motivation, team integration and communication and presentation skills were briefly covered. Mr. Marwan assumes a different anticipation of soft skill keywords with employers seeking applicants and potential employees looking for jobs. ePunkt acts as a mediator between the two parties.

The company operates a distinguished database of people and skill profiles, most of which are technical skills. ePunkt has experimented with natural language analysis in job applications. However, Mr. Marwan does not have a dictionary of denotations for soft skills.

\section{RESULTS}

We evaluated 280 job offers, eliminated 95 duplicates. Thus 185 job offers were used as the basis for statistical analysis. Job profiles ranged from software development (40\%), IT specialists (20\%), service operation personnel (14.6\%), consulting (13.5\%), project management (9.2\%) to sales. Job categorization was overlapping (a software developer could also be team leader for a small development group). $41 \%$ specified skill levels from Junior to Senior. They were distributed nearly evenly (15.7\% to $11.9 \%)$. About $50 \%$ of all job offers demanded higher IT specific or academic education. $12.4 \%$ require specialized education and certification, mostly SAP certifications.

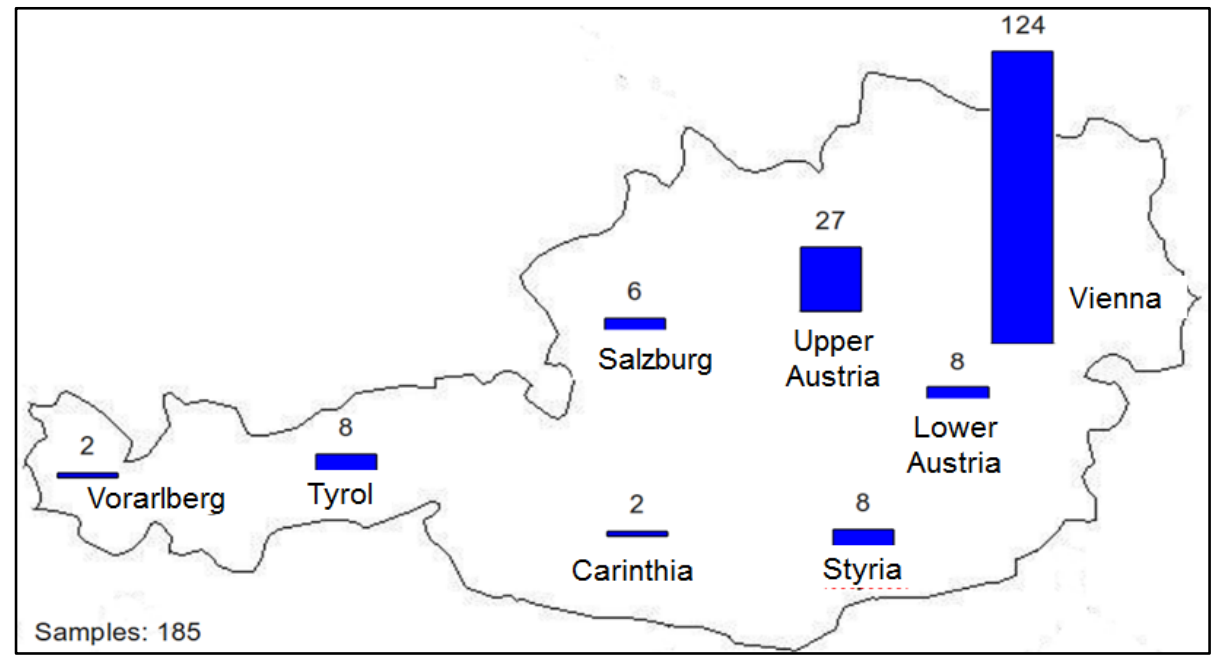

Figure 1: Geographical distribution of vacancies 
Figure 1 shows the distribution of vacancies over the federal territories. Not surprisingly, most job offers were related to vacancies in and around Vienna (124 offers). Upper Austria with Linz and Wels follows as strongholds for innovation (27 offers). The rest (34 offers) were evenly distributed around the other federal states. There was no IT related job offer in Burgenland between March and September 2010.

Figure 2 shows nomination of required soft skills within job offers with command of the English language leading with over 55\%. Self-motivation, team integration and communication skills follow with $49.2 \%$, $40 \%$ and $37.8 \%$ respectively.

Project management skills, while not initially considered being a soft skill was added to the list with nearly one third mention $(29.7 \%)$.

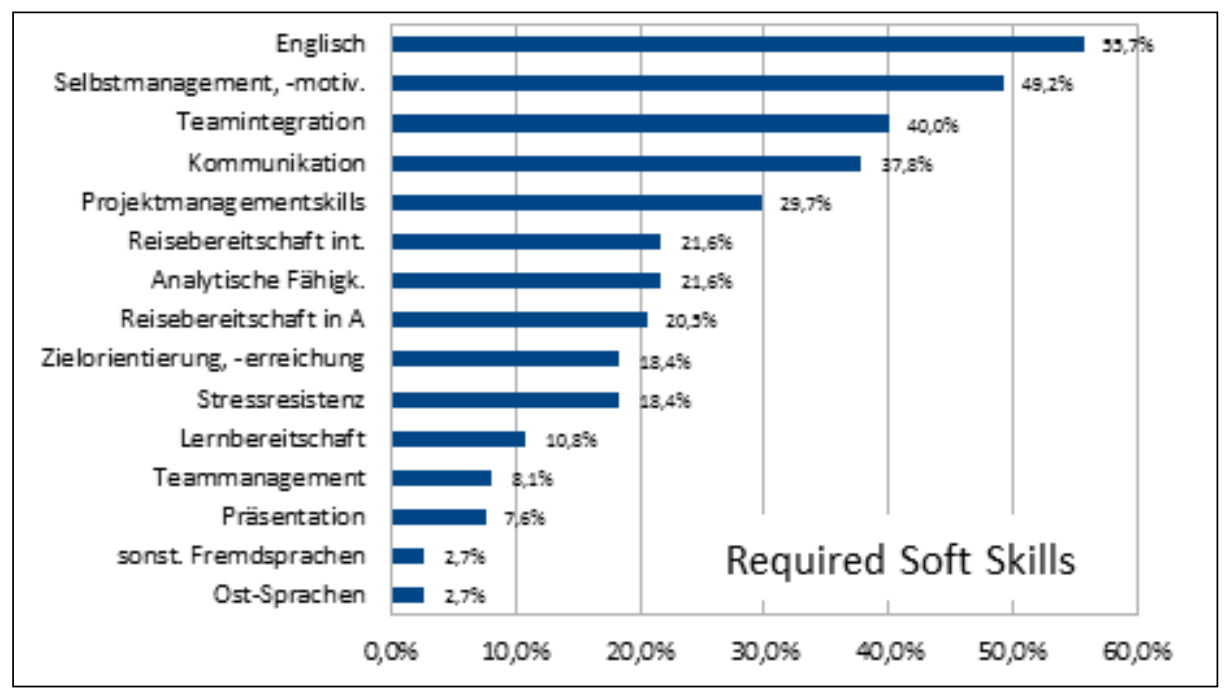

Figure 2: Required Soft Skills

While English takes a prominent role in required foreign languages, others do not (cf. Figure 3). There seems to be little demand for CEE languages spoken in neighbor countries or even others.

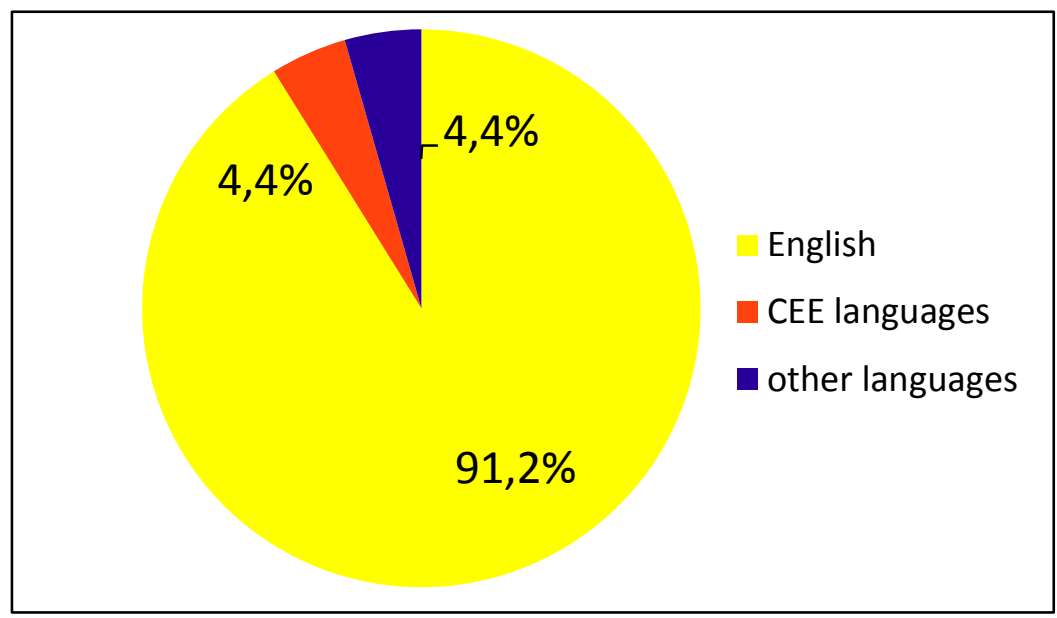

Figure 3: Requirement for foreign languages 


\section{INTERPRETATION}

English is the most prominent soft skill required. Every second job offering requires the applicant to speak it fluently or even up to the level where contracts can be negotiated. Our survey research group found that requirement for English was estimated to be up to $37 \%$. One explanation for this difference might be that most companies in Austria rarely have the need to communicate in English - international companies notwithstanding. Never the less, having a good knowledge in English is more than helpful in IT. Some universities in Austria offer courses held in English. Having non-native speakers giving lectures in a foreign language might introduce a new demand for additional trainings: teaching others in a foreign language.

Self-management and self-motivation (taking responsibility, being responsible, enthusiastic, enduring, helpful) is close number 2 with nearly $50 \%$ mention. This was found also in the survey group with about $80 \%$. We also found attributes like economical and entrepreneurial mindset or structured approach being used as synonyms. Colloquially speaking, employers want their employees to ask little or no questions. It should be clear by the job description in itself, what is required (Daniel Marwan). Universities rarely offer in this - highly demanded - field today. One approach could be to practice workplace communication. Team and group work is enforced regularly. There are some courses in how to apply for jobs. While this is a good starting point, at the University of Applied Sciences Technikum Wien, there is no course on how to organize or chair meetings, how to enquire implicit and explicit requirements and detect "hidden agendas".

Third in our ranking came team integration (being helpful, willing to communicate, being friendly and obliging) with $40 \%$. It also includes the ability to achieve results in groups. Surprisingly, the survey did not provide enough evidence that the ability to integrate into teams was that important. According to Daniel Marwan, team integration is mainly a synonym for not being disturbed and maladjusted. Applicants that fit the corporate culture are identified during job interviews. He is convinced that this paraphrase can be omitted but is demanded during the setup of the job advertisement either by human resource or company representatives. Taking this explanation into account, universities suffice to enforce team work for their practical exercises.

We distinguish between communication skills and presentation skills with communication skills having a $37.8 \%$ rating. Communication skills represent the ability to communicate and cooperate within the company. It includes the ability to use written and spoken language to concisely transfer facts, prepare internal reports, briefings and presentations. Presentation skills resemble the ability to communicate with clients and include a certain degree of persuasiveness. While the latter requirement was found in sales jobs, communication skills are required across branches and job types. These findings coincided with the survey group. Universities regularly require students to give brief presentations, either alone or in groups. They also require their students to provide reports on individual and group self-studies. One potential for improvement would include offering courses in giving briefings, presentations and speeches as well as teaching students in the art of concise writing. Considering current email traffic and the quality of peer communication this seems an important issue to the authors.

Nearly a third of job offers requested project management skills (29.7\%). However, no formal certification in project management (PMI, IPMA, Roland Berger, etc.) was required. The survey group does not offer additional information as project management was not considered a soft skill initially, only turned out during screening of advertisements. Being more precise, this should be phrased "soft project management skills". Being able to work in project teams, being assigned temporarily to specific tasks, represent a group within a working team, being part of a matrix organization and a certain degree of cognitive capabilities are some requirements.

\section{ADDITIONAL OBSERVATIONS}

We referred to Universities in general. However, in Austria there is a difference in the level of formality between traditional universities and universities of applied science like the UAS Technikum Vienna. Universities of applied science seem to be more suited in fulfilling the demands and requirements of the industry, specifically the IT industry. Traditional universities offer more formal and subject oriented education. During screening we also found a domination of ePunkt providing job advertisements. ePunkt operates offices all over Austria. Nearly 64\% of all vacancies were administered by them. As there are just a few recruiters working for Mr. Marwan, there might be a 
significant impact on how and where specific soft skills were placed. This paper and the underlying research does not account for this fact and possible errors introduced. However, there are approximately 450 additional job offers available for further analysis.

\section{CONCLUSION}

This paper tried to answer the question whether there is demand by IT industry for academic training and education covering soft skills. During course we found significant demand for several soft skills, mainly fluent command of English as a general language, self-management and self-motivation, ability to integrate into teams with the specific connotation of cultural conformity, and communication skills with emphasis on concise internal verbal and written interaction. We also brushed on the issue of improvements to course programs universities could offer. While universities of applied science provide a profound basis, we imagine further hints to be helpful: introduction to project management with emphasis on working in project teams, giving concise briefings, speeches and presentations, and peer and customer oriented conversation with emphasis on finding implicit and hidden requirements

\section{AUTHOR INFORMATION}

Harald Wahl, Institute of Information Engineering and Security, UAS Technikum Wien, Hoechstaedtplatz 5, 1200 Vienna, Austria. E-mail: wahl@ @echnikum-wien.at. Corresponding author.

Christian Kaufmann, Institute of Information Engineering and Security, UAS Technikum Wien; Austria

Florian Eckkrammer, Institute of Business Informatics, UAS Technikum Wien; Austria

Alexander Mense, Institute of Information Engineering and Security, UAS Technikum Wien; Austria

Helmut Gollner, Institute of Business Informatics, UAS Technikum Wien; Austria

Christian Himmler, UAS Technikum Wien; Austria

Wolf Rogner, UAS Technikum Wien; Austria

Thomas Baierl, UAS Technikum Wien; Austria

Roman Slobodian, UAS Technikum Wien, Austria

\section{REFERENCES}

1. AMS qualification barometer, http://bis.ams.or.at/qualibarometer/qualistruktur.php (online visited on September $\left.15^{\text {th }} 2011\right)$.

2. $\quad$ Baumgartner, P. P., Hornbostel, R. (2007). Manager müssen Mut machen. Mythos Shackleton. Führungskunst - Unternehmensphilosophie - Neuausrichtung. Boehlau Verlag.

3. Borghans, L., Green, F., Mayhew, K. (2001). Skills Measurement and Economic Analysis: An Introduction. Oxford Economic Papers, Oxford University Press, vol. 53(3), pages 375-84, July.

4. Martins, J., Duarte, M., Reis Cunha, S., Almada Lobo, B., Torres Marques, A., Magalhães, B. (2007). The role of hard and soft skills on engineering education. In Proceedings of the International Conference on Engineering Education (ICEE) 2007, pp.1-6, September 3-7, Coimbra, Portugal.

5. Pulko, S. H., Parikh, S. (2003). Teaching soft skills to engineers, International Journal of Electrical Engineering Education (IJEEE), Vol. 40, pages 243-254, October 2003, ISSN 0020-7209.

6. Russell, J., Russell, B., Tastle, W. J. (2005). Teaching soft skills in a systems development capstone class. Information Systems Education Journal, 3(19). http://isedj.org/3/19/. ISSN: 1545-679X.

7. Schulz, B. (2008). The importance of soft skills: Education beyond academic knowledge. Nawa Journal of Communication, 2(1), 146-154. 
NOTES 